\title{
Article
}

\section{High cost drugs}

Davies, Janice Anne

Available at http://clok.uclan.ac.uk/39276/

Davies, Janice Anne (2021) High cost drugs. Journal of Prescribing Practice, 3 (9). p. 350. ISSN 2631-8385

It is advisable to refer to the publisher's version if you intend to cite from the work.

10.12968/jprp.2021.3.9.350

For more information about UCLan's research in this area go to

http://www.uclan.ac.uk/researchgroups/ and search for < name of research Group>.

For information about Research generally at UCLan please go to http://www.uclan.ac.uk/research/

All outputs in CLoK are protected by Intellectual Property Rights law, including Copyright law. Copyright, IPR and Moral Rights for the works on this site are retained by the individual authors and/or other copyright owners. Terms and conditions for use of this material are defined in the policies page.

\section{CLoK}

Central Lancashire online Knowledge www.clok.uclan.ac.uk

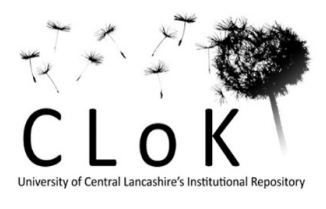


Author accepted manuscript:

https://doi.org/10.12968/jprp.2021.3.9.350

\section{$\underline{\text { High-Cost Drugs }}$}

As prescribers we all have a responsibility to use NHS resources judiciously. CCG medicines management teams can produce prescribing reports to help prescribers to identify specific instances of high-cost drug prescribing in primary care, for example, where the monthly prescribing cost exceeds $\mathrm{f200}$ per month. Analysis of these reports is useful for several reasons:

It could prompt a review of the patient's treatment. In some cases, if clinically appropriate, it may be possible to replace the high-cost drug with a more cost-effective preparation

It is an opportunity to check whether any of the high-cost drugs on the report are centrally commissioned drugs (eg cancer drugs) or are designated in the local formulary as 'red traffic light'. In these cases prescribing should be repatriated to the most appropriate specialist to ensure correct monitoring and review of the patient.

Complete the table (Table 1) to calculate the monthly and annual cost of the following drugs:

\begin{tabular}{|l|l|l|l|l|}
\hline & $\begin{array}{l}\text { Pack price (based } \\
\text { on Drug Tariff } \\
\text { August 2021) }\end{array}$ & $\begin{array}{l}\text { Number of } \\
\text { prescriptions } \\
\text { issued per } \\
\text { month }\end{array}$ & Cost per month & $\begin{array}{l}\text { Annual cost } \\
\text { (assume 13 } \\
\text { prescriptions } \\
\text { per year) }\end{array}$ \\
\hline $\begin{array}{l}\text { Haloperidol 500 } \\
\text { microgram tablets }\end{array}$ & $\begin{array}{l}28 \text { tablets }= \\
f 139.74\end{array}$ & 2 & & \\
\hline $\begin{array}{l}\text { Ethosuximide } \\
250 \mathrm{mg} \text { capsules }\end{array}$ & $\begin{array}{l}56 \text { capsules }= \\
f 194.05\end{array}$ & 3 & & \\
\hline $\begin{array}{l}\text { Famciclovir 250mg } \\
\text { tablets }\end{array}$ & $21=f 258.03$ & 1 & & \\
\hline $\begin{array}{l}\text { lanreotide 120mg } \\
\text { pre-filled syringe }\end{array}$ & 1 syringe $=£ 551$ & 4 & & \\
\hline $\begin{array}{l}\text { Atropine sulphate } \\
\text { eye drops 1\% }\end{array}$ & $10 \mathrm{ml}=£ 131.89$ & 3 & & \\
\hline
\end{tabular}

